\title{
Plant Adaptation Regions: Ecological and Climatic Classification of Plant Materials
}

\author{
K. P. Vogel, ${ }^{1}$ M. R. Schmer, ${ }^{2}$ and R. B. Mitchell ${ }^{3}$ \\ Authors are ${ }^{1}$ Research Geneticist, ${ }^{2}$ Biological Science Technician, and ${ }^{3}$ Rangeland Scientist, USDA-ARS, 344 Keim Hall, \\ University of Nebraska, PO Box 830937, Lincoln, NE 68583-0937.
}

\begin{abstract}
The effective use of plant materials for an array of objectives including conservation, restoration, renovation, landscaping, and bioremediation requires knowledge of the adaptation of each species and, more specifically, knowledge of the adaptation of cultivars, strains, accessions, or ecotypes of a species to specific sites or regions. For agronomic and horticultural plants, specific adaptation information has been and continues to be developed by extensive testing. Rangeland, grassland, park, and restoration project managers often lack the resources to determine adaptation areas for plant materials because of the large number of species that are used and the extensive geographical areas that are serviced. Problems often arise in delineating adaptation areas for plant materials of both native and introduced species. Since ecoregion and plant hardiness zone classification systems integrate many climatic and geographic variables that determine plant adaptation, these 2 systems can be combined to develop Plant Adaptation Regions (PARs). A PAR map of the contiguous United States was developed by merging a widely used ecoregion map with the USDA Plant Hardiness Zone map, and is available in GIS format. Based on their geographic origins and/or test results, plant materials and their general areas of adaptation can be classified using PARs.
\end{abstract}

\section{Resumen}

El uso efectivo de materiales de plantas para un grupo de objetivos, incluyendo la conservación, restauración, renovación, jardinería y bioeremediación, requiere del conocimiento de la adaptación de cada especie, y más específicamente de los cultivares, líneas o ecotipos de una especie a regiones o sitios específicos. En el caso de especies hortícolas o de uso agronómico la información sobre la adaptación específica ha sido y continua siendo desarrollada mediante la pruebas extensivas. Sin embargo, los manejadores de proyectos de restauración de pastizales, parques y praderas a menudo carecen de recursos para determinar las áreas de adaptación para las especies vegetales debido al gran número de especies que son usadas y las áreas geográficas tan extensas en las que son evaluadas. Los problemas a menudo surgen en delinear áreas de adaptación para los materiales vegetales tanto de especies nativas como introducidas. Dado que los sistemas de clasificación de ecoregiones y zonas de resistencia de las plantas integran muchas variables climáticas y geográficas que determinan la adaptación de las plantas, ellas pueden se combinadas para desarrollar Regiones de Adaptación de Plantas (PAR). Un mapa PAR adyacente de Estados Unidos se desarrollo uniendo un mapa de ecoregión, ampliamente utilizado y un mapa de Zona de Resistencia de Planta del Departamento de Agricultura de los Estados Unidos (USDA) que esta disponible en formato de sistemas de información geográfica (GIS). Basados en su origen geográfico y/o resultados de evaluaciones, los materiales de plantas y sus áreas generales de adaptación pueden ser clasificadas usando las Regiones de Adaptación de Plantas.

Key Words: ecoregion, plant hardiness zone, ecotypes, plant germplasm, cultivars, native plants

\section{INTRODUCTION}

Millions of hectares of land in North America need renovation because of natural or human-induced disturbances. The effective use of plant materials for an array of objectives requires knowledge of the adaptation of each species and, more specifically, its plant materials or germplasm, which includes cultivars, strains, accessions or collections, or ecotypes of a species to specific sites or regions. For agronomic and horticultural crops,

Journal series 14273, Nebraska Agricultural Experiment Station.

Mention of a trade name does not constitute a guarantee of the product by USDA or the University of Nebraska and does not imply its approval to the exclusion of other suitable products.

Correspondence: K. P. Vogel, USDA-ARS, 344 Keim Hall, University of Nebraska, PO Box 830937, Lincoln, NE 68583-0937. Email: kpv@unlserve.unl.edu

Manuscript received 19 January 2004; manuscript accepted 26 October 2004. substantial research resources are often available, and specific adaptation information is developed by extensive testing. Other users of plant materials, such as rangeland and natural area managers, often lack the resources to determine adaptation of specific plant materials because of the large number of species that are used and the extensive geographical areas that are serviced.

Plant ecologists and biogeographers have developed systems that classify the natural ecoregions of the earth (Bailey 1998b; Brown et al. 1998). These classification systems are similar, but differ in the hierarchical arrangements used. Bailey (1995, 1997, 1998a, 1998b) developed revised hierarchical descriptions of the ecoregions of the United States, North America, and the world.

Ecoregion subzones or provinces such as savanna, steppe, or tundra are characterized by classes of dominant plant formations and are correlated to major soil groups, as climate strongly affects major soil-forming processes. Ecoregion provinces of 


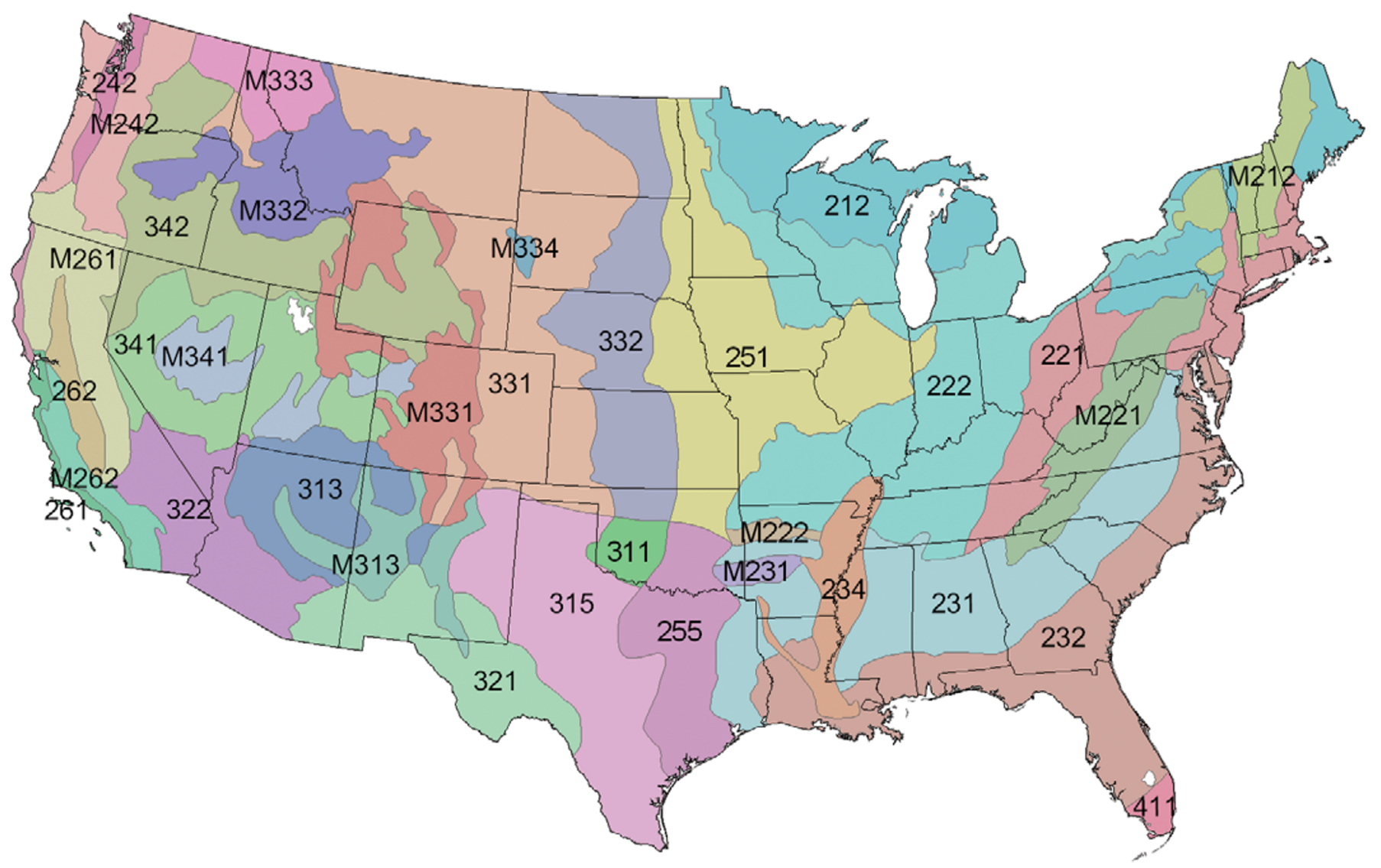

Figure 1. Ecoregions map of the 48 contiguous United States (Bailey 1997, 1998a). Sample ecoregion provinces include 251 (Prairie ParklandTemperate), 331 (Great Plains-Palouse Dry Steppe), and 332 (Great Plains Steppe). See http://www.fs.fed.us/colorimagemap/ecoreg1_provinces for complete ecoregion descriptions.

North America (Bailey 1997, 1998a, 1998b) such as the Prairie Parkland (Province 251) and the Great Plains Steppe (Province 332) cover large geographical areas, and each is dominated by a common set of adapted species (Fig. 1). Different areas of the world can have the same or similar ecoregion classifications. For example, ecoregions similar to savanna, steppe, or tundra are found in several continents in addition to North America (Bailey 1998b). Plant species native to a specific ecoregion in North America will likely be well adapted to the same ecoregion on other continents, and vice versa. Thus, ecoregions can be used to characterize adaptation of both native and introduced plants at the species level. In a comparison of 5 regional-scale ecological classification schemes, Steiner and Greene (1996) concluded that Bailey's ecoregions scheme was the best descriptor for regional classification of germplasm because of its hierarchical arrangement; the number of distinctive classes based on soils, landform, and natural vegetation; and its availability in a Geographical Information System (GIS) format.

The importance of climate to the adaptation of widely distributed temperate species has been previously described (Steiner and Greene 1996; Steiner 1999). Ecoregion provinces can cover wide zones of latitude. Latitude affects day length during the growing season, length of the growing season, and temperature during both the growing and nongrowing or dormant seasons. Plant populations within an ecosystem often become adapted to their specific latitude via common flowering and maturity characteristics. Populations of a species from different latitudinal zones within an ecoregion can be differentiated by growing the populations in common nurseries located at different latitudes within the ecoregion (Cornelius and Johnston 1941; McMillian 1959, 1965; McMillian and Weiler 1959; Phan and Smith 2000). These differentiated populations can be referred to as ecotypes (Moser and Vogel 1995). A species within an ecoregion is not genetically uniform in regards to adaptation to the entire ecoregion, but is stratified into a northto-south latitudinal gradient or a high-to-low elevation gradient of ecotypes that are best adapted to their own specific areas of the ecoregion. As an example, when grown in the central Great Plains, switchgrasses (Panicum virgatum $\mathrm{L}$.) from the Dakotas (northern ecotypes) flower and mature early and are short in stature, whereas those from Texas and Oklahoma (southern ecotypes) flower late and are tall (Cornelius and Johnston 1941; McMillian 1959). Moving northern ecotypes south gives them a shorter than normal photoperiod, and they flower early. The opposite occurs when southern ecotypes are moved north, and as a result they stay vegetative longer and produce more forage than do the northern strains moved south (Newell 1968). The photoperiod response also appears to be responsible for winter survival. Southern types moved too far north will not survive.

The effects of latitude on temperature, winter conditions, and plant growing-season duration within an ecoregion can be 


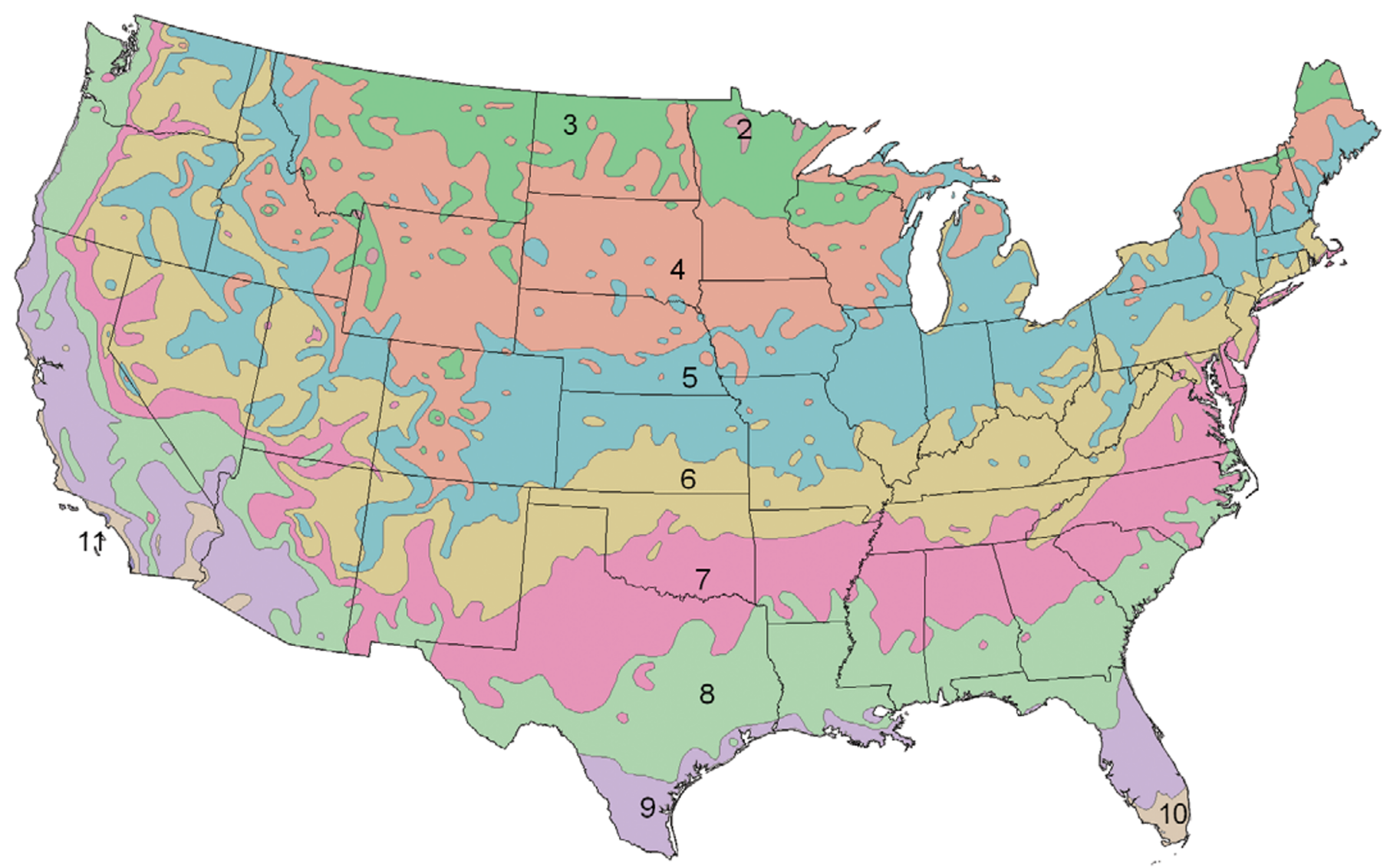

Figure 2. USDA Plant Hardiness Zone map for the United States, minus Alaska and Hawaii. Range of average annual minimum temperatures ( $\left.{ }^{\circ} \mathrm{C}\right)$ by Hardiness Zone: Zone 1, below -45.6; Zone 2, -45.5 to -40.0; Zone 3, -39.9 to -34.5; Zone 4, -34.5 to -28.9; Zone 5, -28.8 to -23.4; Zone 6, -23.3 to -17.8 ; Zone $7,-17.7$ to -12.3 ; Zone 8, -12.2 to -6.7 ; Zone 9, -6.6 to -1.2 ; Zone 10, -1.1 to 4.4; Zone 11, above 4.5.

modified by geographical features such as the Great Lakes of North America, mountains, and oceans. Plant Hardiness Zones (HZ) such as the USDA Plant Hardiness Zones (Fig. 2) for North America have been developed to classify plants to hardiness or survival zones, which are essentially latitudinal climatic zones modified by nonlatitudinal geographic features. These HZs are in gradients of $5.5^{\circ} \mathrm{C}\left(10^{\circ} \mathrm{F}\right)$. As an example, $\mathrm{HZ} 6$ has an average minimum temperature of -18 to $-13{ }^{\circ} \mathrm{C}\left(0\right.$ to $\left.9^{\circ} \mathrm{F}\right)$.

An increased demand exists for native species for use in conservation, rangeland and roadside plantings, parks, residential and commercial landscape projects, golf courses, and bioremediation. Native species are often preferred for these uses because of their persistence, their low maintenance, and their ecological and aesthetic attributes, including biological diversity and value to wildlife. There is currently limited information on the adaptation regions for native species. Resources for extensive testing are often lacking, and no structure exists for delineating evaluation regions. The ability to predict adaptation areas of native plant cultivars and germplasm is necessary for their successful utilization. The objectives of this report are to describe a plant adaptation classification system and an associated map produced by combining ecoregions and hardiness zone maps to develop "Plant Adaptation Regions" (PARs), and to provide examples of their use.

\section{MATERIALS AND METHODS}

A map of PARs can be produced by combining ecoregion maps with plant hardiness zone maps. The ecoregion maps of the world and North America developed by Bailey $(1995,1997,1998$ a, 1998b), which are in the public domain and readily available via the Internet (www.fs.fed.us/colorimagemap/ecoreg1_provinces. html), can be used for this purpose. The Ecoregions Map of North America (Fig. 1) (Bailey 1997, 1998a) is being used by several conservation organizations. The USDA Plant Hardiness Zone Map (Fig. 2) (Cathey 1990) is likewise in the public domain and available via the Internet (www.usna.usda.gov/Hardzone/ ushzmap.html). A PAR map (Fig. 3) was developed by integrating Bailey's ecoregion map and the USDA Plant Hardiness Zone map using ArcGIS (ArcInfo edition, ESRI, Redlands, CA). The GIS versions of Bailey's ecoregion map and the USDA Plant Hardiness Zone map were obtained via the Internet and the U.S. National Arboretum (see Cathey 1990), respectively, and merged using the geoprocessing wizard of the ArcMap component of ArcInfo. The intersect method of this software procedure combines the attribute data of the 2 map features into a single map feature. The PAR map is available from the authors and can be used with ArcGIS, ArcView, and ArcInfo software (ESRI). A PAR database is available in ArcGIS format; it can be used to develop more detailed maps for specific regions of the USA. 


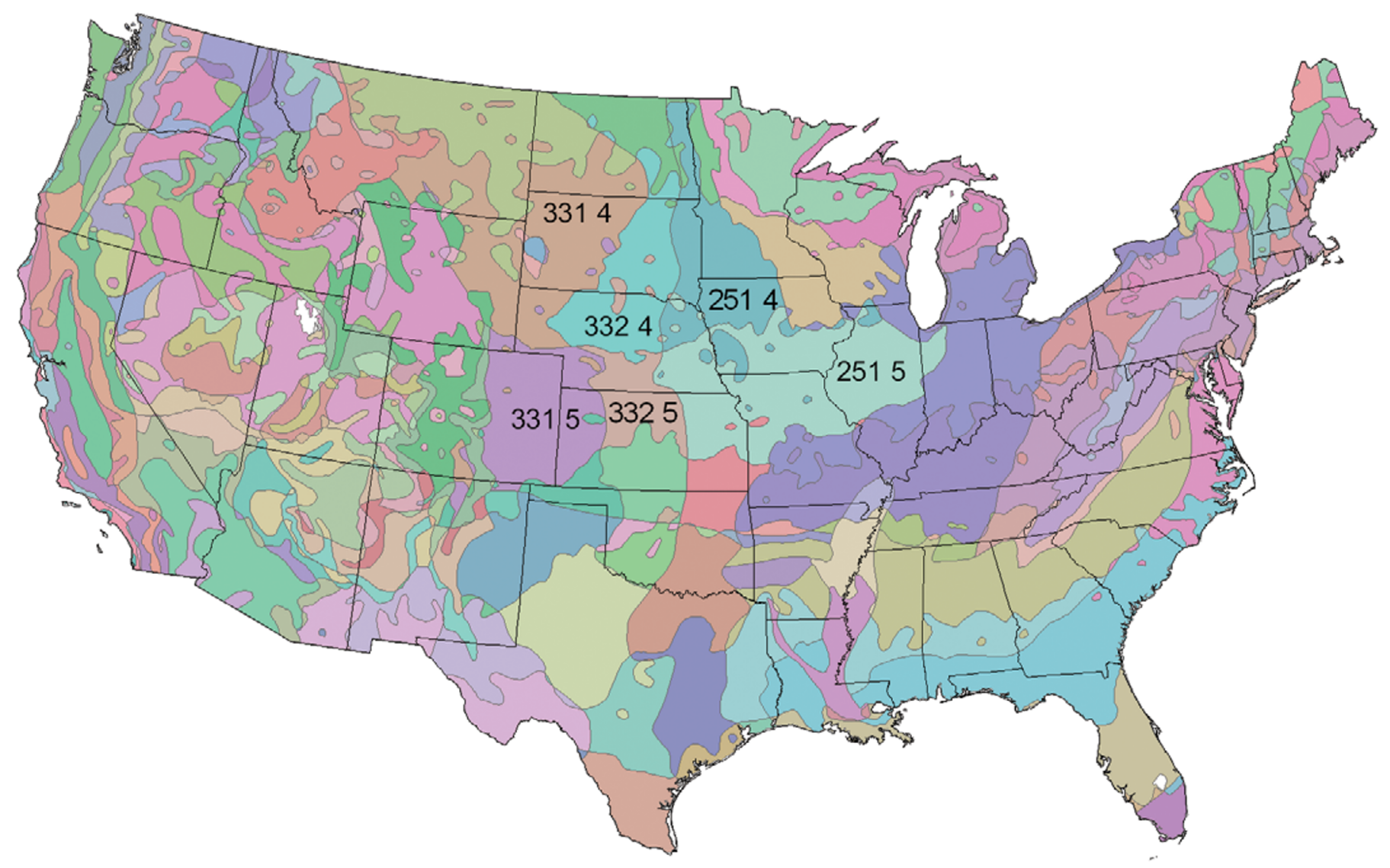

Figure 3. Plant Adaptation Region map for the United States minus Alaska and Hawaii with the following labeled PARs: PAR 331-4, PAR 331-5 = Great Plains Palouse Dry Steppe HZ4 and HZ5, respectively; PAR 332-4, PAR 332-5 = Great Plains Steppe HZ 4 and HZ5, respectively; PAR 251-4, PAR 251-5 = Prairie Parkland Temperate HZ 4 and HZ5, respectively.

\section{RESULTS AND DISCUSSION}

The PAR map for the contiguous United States contains 145 PARs (Fig. 3). As an example of its scope, the Prairie Parkland Ecoregion (Province 251) occupies HZs 3 through 7; the PARs in this province, from north to south, include PAR 251-HZ3 through PAR 251-HZ7.

The geographical origin of most of the germplasm that was used to develop specific cultivars of native species such as switchgrass is known, and previously released cultivars can be classified by their PAR of origin. The PAR classification system is fully compatible with previously published adaptation research for North American prairie grasses (Casler et al. 2004; Hopkins et al. 1995a, 1995b; Newell 1968). Some cultivars have been extensively tested and are widely adapted; they can be classified by PAR adaptation based on trial results in addition to origin PAR. To be adapted, plant material must survive, persist, and be as productive as the original native vegetation. As an example, the switchgrass cultivar Cave-inRock is adapted to ecoregion Province 251 east through most ecoregions to the Atlantic Ocean in HZs 5, 6, and 7 (Moser and Vogel 1995; Vogel 2004). Since the geographical origin of almost all native plant cultivars and germplasm accessions of other species is known, it will be possible to classify them according to their origin or "home" PAR.
PARs provide an ecological and climatic structure for selecting sites to evaluate plant materials both within and outside of their area of origin. Because PARs provide a single mechanism for jointly classifying germplasm and adaptation areas, they can be used to structure collection and evaluation of plant materials. If the plant material of a species is classified by PAR using collection site information, the plant material is essentially being classified for its likely photoperiod sensitivity and response, growing season requirements, climatic characteristics of its area of origin, and areas of potential adaptation. The use of PARs in rangeland and natural area restoration will enable the plant materials of an array of species to be assigned to areas for utilization even though extensive testing may not be feasible because of limited resources. In addition, we are currently using PARs as a guide for combining germplasm collected from prairie sites to develop populations and cultivars of native grasses and forbs for specific geographic regions.

There are some limitations to the use of PARs. The lack of precise boundaries in natural environments should be recognized. Both Bailey's ecoregion concept and plant hardiness zones attempt to define areas of plant adaptation based on environmental factors that gradually change across the landscape. Because of the gradual change in environmental factors that control plant growth, any system that provides discrete geographical boundaries based on these factors is not absolute 
but requires judgment on the part of the users. In addition, there may be significant local adaptation factors that are not differentiated by PARs, such as saline soils. Adaptation information for prairie grasses such as switchgrass in the Great Plains and Midwest is relatively abundant compared to other native species for which limited or no information is available. The robustness of the PAR system for a large number of species has yet to be determined. Although the PAR map and database that we have developed is for the contiguous United States, climatic and ecological maps are available in GIS format for many other regions of the world, and these maps could be also used to develop PARs.

\section{ACKNOWLEDGMENT}

The authors wish to thank Associate Editor James Ansley for his editorial work, which significantly improved the manuscript.

\section{LITERATURE CITED}

Balley, R. G. 1995. Description of the ecoregions of the United States. 2nd ed. Washington, DC: U.S. Forest Service. Misc. Publ. 1391 (rev). 108 p. with separate map at $1: 7,500,000$.

Balley, R. G. 1997. Ecoregions of North America (rev.) [map]. Washington, DC: U.S. Forest Service in cooperation with The Nature Conservancy and the U.S. Geological Survey. Available at: http://www.fs.fed.us/colorimagemap/ ecoreg1_provinces. Accessed 1 September 2004.

Balley, R. G. 1998a. Explanatory note for ecoregions map. Washington, DC: U.S. Forest Service. Misc. Publ. 1548. 10 p.

Balley, R. G. 1998b. Ecoregions: The ecosystem geography of the oceans and continents. New York, NY: Springer-Verlag. 176 p.

Brown, D. E., F. Reichenbacher, and S. E. Franson. 1998. A classification of North American biotic communities. Salt Lake City, UT: University of Utah Press.

Casler, M. D., K. P. Vogel, C. M. Taliaferro, and R. E. Wynia. 2004. Latitudinal adaptation of switchgrass populations. Crop Science 44:293-403.

CATHEY, H. M. 1990. USDA plant hardiness zone map [map]. Washington, DC: U.S.
Department of Agriculture. USDA Misc. Pub. No. 1475. Available from: U.S. National Arboretum, Agricultural Research Service, USDA, Washington, DC 2002. Also available at: http://www.usna.usda.gov/Hardzone/ushzmap.html. Accessed 1 September 2004.

Cornelius, D. R., and C. 0. Johnston. 1941. Differences in plant type and reaction to rust among several collections of Panicum virgatum $\mathrm{L}$. Journal of the American Society of Agronomy 33:115-124.

Hopkins, A. A., K. P. Vogel, K. J. Moore, K. D. Johnson, and I. T. Carlson. $1995 \mathrm{a}$. Genotype effects and genotype by environment interactions for traits of elite switchgrass populations. Crop Science 35:125-132.

Hopkins, A. A., K. P. Vogel, K. J. Moore, K. D. Johnson, and I. T. Carlson. 1995b. Genetic variability and genotype $x$ environment interactions among switchgrass accessions from the Midwestern USA. Crop Science 35:565-571.

McMılLıAN, C. 1959. The role of ecotypic variation in the distribution of the central grassland of North America. Ecological Monographs 29:285-308.

McMıLlıA, C. 1965. Ecotypic differences with four North American prairie grasses: ii. behavioral variation with transplanted community fractions. American Journal of Botany 52:55-65.

McMillian, C., And J. Weller. 1959. Cytogeography of Panicum virgatum in central North America. American Journal of Botany 46:590-593.

Moser, L. E., AND K. P. Vogel. 1995. Switchgrass, big bluestem, and indiangrass. In: R.F. Barnes, D. A. Miller, and C. J. Nelson [eds.] Forages. Volume I: An introduction to grassland agriculture. 5th ed. Ames, IA: Iowa State Univ. Press. p 409-420.

NeweLL, L. C. 1968. Effects of strain source and management practice on forage yields of two warm-season prairie grasses. Crop Science 8:205-210.

Phan, A. T., And S. R. Smith, JR. 2000. Seed yield variation in blue grama and little bluestem plant collections in southern Manitoba, Canada. Crop Science 40: $555-561$.

SteineR, J. J. 1999. Exploring the relationship of plant genotype and phenotype to ecogeography. In: S.L. Greene and L. Guarino [eds.]. Linking genetic resources and geography: Emerging strategies for conserving and using crop biodiversity. Madison, WI: ASA-CSSA-SSSA. CSSA Spec. Publ. 27. p 39-50.

Steiner, J. J., And S. L. Greene. 1996. Proposed ecological descriptors and their utility for plant germplasm collections. Crop Science 36:439-451.

VogeL, K. P. 2004. Switchgrass. In: L.E. Moser, L. Sollenberger, and B. Burson [eds.]. Warm-season $\left(\mathrm{C}_{4}\right)$ grasses. Madison, WI: ASA-CSSA-SSSA Monograph. p 561-588. 